\title{
THE INSTRUCTIONAL PRACTICES OF SECONDARY SCHOOL TEACHERS IN ETHIOPIA: HULET EJU ENESIE WOREDA
}

\author{
Bizu Kinfe Zekiros ${ }^{{ }^{*}}$ 凶 (iD) \\ ${ }^{*_{1}}$ MSC in Curriculum and Instruction in Collage of Education and Behavioral Science, Bahir Dar \\ University, Ethiopia
}

DOI: https://doi.org/10.29121/granthaalayah.v8.i11.2020.1682

Article Type: Research Article

Article Citation: Bizu Kinfe Zekiros. (2020). THE INSTRUCTIONAL PRACTICES OF SECONDARY SCHOOL TEACHERS IN ETHIOPIA: HULET EJU ENESIE WOREDA. International Journal of Research GRANTHAALAYAH, 8(11), 53-62. https://doi.org/10.29121/granthaa layah.v8.i11.2020.1682

Received Date: 20 September 2020

Accepted Date: 25 November 2020

Keywords:

Instructional Design

Instructional Practices

Instruction Model

\section{ABSTRACT}

This study was examined secondary school teachers' instructional practices by using First Principle of Instruction model as guiding principle. Both qualitative and quantitative methods were employed. The total populations of the study were 52 . From these 40 Biology teachers, 4 directors, 4 supervisors and 4 department heads were selected through comprehensive sampling technique. Data were obtained through questionnaire, interview, classroom observation and document analysis. Various statistical tools such as mean, frequency and percentage were applied to analyze the data. The finding indicated that secondary school Biology teachers design their lessons by using First Principle of Instruction Model and they practiced it partially. And biology teacher's instructional practices are aligned partially with First Principle of Instructional Model. Some factors that affect the design and implementation of the lessons based on the First Principle of Instruction model were identified: teachers' related problems, students related problems, time constraints, policy issues, and resources. Based on the finding, it is recommended that woreda education office and general secondary schools should have to prepare short- and long-term training, seminars and workshop for teachers. Secondary school directors and supervisors should help teachers to have personal, professional knowledge and pedagogical skill. They should also support them by creating good educational environment.

\section{INTRODUCTION}

\subsection{BACKGROUND OF THE STUDY}

To be effective in an educational system, a clear instruction that is directly related to the socio- economic realities of a given country need to be devised. Instruction can be defined as a plan for teaching and learning activities in which learning is systematically organized (Smith \& Ragan, 2005). In designing effective learning environment, the principle of instruction includes teacher's behavior in designing instruction, grouping practice and effective delivery. Teachers' behaviors are related to teachers' action with beginning a lesson, presenting information, guiding student practice after instruction, correcting students' work and providing feedback, planning students' work. Teachers' perception plays an influential role in determining their professional behavior. The way they plan their lesson, the kind of decision they make and the way they apply different instruction in their classroom. Those instructional models promote instructional design principles that are based on the notion that the teachers

(C) 2020 The Author(s). This is an open access article distributed under the terms of the Creative Commons Attribution License, which permits unrestricted use, distribution, and reproduction in any medium, provided the original author and source are credited. 
The Instructional Practices of Secondary School Teachers in Ethiopia: Hulet Eju Enesie Woreda

must create learning environments in which students articulate, define and modify their ideas (Daggett, 2011). Effective instructional design can support students' achievement by engaging them as active and independent learners, stimulates students' domain specific content knowledge (Tiruneh et. al., .2015). Moreover, various studies have shown that designing effective lesson promotes collaborative learning (Kali, 2009), increase student motivation to teach (Gardner, 2011), develop metacognitive skill (Melesse, 2015) and facilitate the transfer of acquired knowledge to solve authentic tasks (Merrill, 2002).

Student learn best when instruction is appropriately challenging, based on real world problem purposeful and interesting (Merrill, 2009). This implies that teachers should design effective learning environment that may enhance students' subject-matter and daily life knowledge. In this case, effective learning environment is the process of creating opportunities for facilitating or increasing students learning.

There are different models of instructional design. E.g ASSURE Model,Gagne's Model, Keller's ARCS Model, Dick and Carey Model, ADDLE Model, Merrill's First Principle of Instruction Model. From these models the researcher selects Merrill's First Principles of Instruction Model. Because this model is more focused on authentic tasks or problems of students in their real life and M David Merrill (2002) provide a coherent comprehensive over view of instructional design principle for an eclectic perspective, incorporating behaviorists, cognitivists and constructivists

Moreover, many new instructional theories advocate that centering instruction around a set of authentic tasks helps to improve application and transfer of knowledge and helps students to take more responsibilities for their own learning (Francom et, al, 2009; Merrill, 2006 2007). Therefore, it is important to design instruction with task related issues so that students can have both subject matter and everyday life knowledge.

\section{STATEMENT OF THE PROBLEM}

Different countries in the world acknowledge that the quality of secondary school education is pillar for national development. That means improving the quality of secondary school education is considered as key elements for the growth of education. To ensure and offer quality education for secondary schools, teachers should plan and implement different instructional strategies. It is the teachers' knowledge, competence and ability of planning their instruction effectively could bring the best from the learner in terms of academic achievements (Micheal et al, 2012). Similarly, to achieve modern aims of education, it's very much important to focus more attention on the training of teachers to acquire knowledge and skill in instructional design related principle of the effective instruction and also it is very important to expose learner to the effective principle of instruction.

In most Ethiopian secondary schools, teachers' instructional practices are focused on lecture-based instruction in which a teacher provides information to students verbally in the classroom and includes a few or no additional learning activities (Melesse, 2015). But it is important that allowing students' sufficient time to engage in the progression of task in subject matter area will enable learner to apply and solve problem in their real world (Francom et. al., 2009). Ethiopian secondary school teachers have many problems during designing lesson plan which Lack of adequate support, lack of interest, commitment and motivation to their profession, attitudinal problems (Melesse, 2015).

Research on teachers' instructional practice revealed that teachers plan their lesson with content and learning activities as opposed to the rational model of planning. The teachers' approach to lesson planning reflects their own perception (Simegn, 2012).

Survey research was conducted by Simegn (2012), in secondary school teachers' pedagogical believes and instructional practice. This study revealed that teachers seem to have unrealistic interest and competence to their teaching profession and they did not seem to have a clear idea about the focus of instruction. Since effective instructional practice can contribute and help towards the improvement of students' performance, it would be beneficial to study how teachers' design and implement their instruction effectively. Because most teachers have limited knowledge, attitude and experience in designing their lesson systematically. The main purpose of this study is therefore to examine the extent to which secondary school biology teachers design and implement their lessons. Biology course was selected because science education is limited in Ethiopia generally and students perform poorly in various science subjects including biology (Daba \& Anbesaw, 2016). Therefore, the following research questions were posed by the researcher. 


\section{RESEARCH QUESTIONS}

How do secondary school biology teachers design and implement their lessons in HuletEjuEnesieWoreda?To what extent do the instructional practices of secondary school biology teachers align with the First Principles of Instruction model in HuletEjuEnesieWoreda?What are the major challenges of secondary school biology teachers of design instruction that implement the First Principle of Instruction Model in HuletEjuEnesieWoreda?

\section{OBJECTIVES OF THE STUDY}

The general objective of this study was to examine the design and implementation of secondary school biology lessons in line with the First principles of instructional model and find out the possible reasons that affect the alignment. Specifically, the study intends to:

1) To know secondary school biology teachers' design and implement their lessons in HuletEjuEnesieWoreda

2) To examine the instructional practices of secondary school biology teachers', align with the First Principles of Instruction model in HuletEjuEnesieWoreda.

3) To identify the major challenges of secondary school biology teachers of design instruction those implement the First Principle of Instruction Model in HuletEjuEnesieWoreda.

\section{RESEARCH METHODS}

For this study, descriptive survey and both qualitative and quantitative research method design were employed. Descriptive survey design is a scientific method which involves observing and describing the behavior of the subjects without influencing it in any ways (Creswell, 2012). And it is also appropriate and more effective to investigate the current instructional practices of teachers. It provides a better understanding of the targeted research problem. Mixed method design is one in which both qualitative and quantitate method are used to answer the research question in single study.

\section{SAMPLE AND SAMPLING TECHNIQUES}

In HuletEjuEnesieworeda, there are four government general secondary schools. In those schools, there are 40 biology teachers. The samples (biology teachers) are selected by comprehensive sampling technique. Accordingly, all biology teachers $(\mathrm{N}=40)$ were participated in this study. In addition, four directors, four supervisors and four department heads were selected through comprehensive sampling technique for additional information about teachers' instructional practices and how the school support teachers to design effective instruction in the actual classrooms. Therefore, the total sample size is 52.

\section{DATA COLLECTION INSTRUMENTS}

Questionnaire, interview, classroom observation and document analysis were employed to collect the data.

Questionnaire: To obtain the required information, closed and open-ended type of questionnaires were prepared. They were adapted from Merrill (2006) and modified. Questions were structured with three points of rating scales. These rating scales range from Always, Sometimes and Never, respectively. The final questionnaire has two sections. The first section was intended to collect background information about the participants, and the second part helps to assess information regarding respondents' whole instructional practice.

Interview: Interview items were constructed based on the proposed model that is first principle of instruction model. The interview was conducted with the directors, supervisors and department heads. The main goals of the interview were to get additional information about teacher's instructional practices and how the school support teachers to design effective instruction in the actual classroom.

Observation: Classroom observation was another instrument for collecting relevant data. The main goal of this instrument is to see teachers' practices of instruction in the actual classroom. Based on the proposed instruction model which means 'First Principle of Instruction Models', classroom observation checklist was prepared and the 
The Instructional Practices of Secondary School Teachers in Ethiopia: Hulet Eju Enesie Woreda

researcher observed four different teachers three times in each classroom from each school. That means $4 * 3 * 4=48$ session was observed.

Document analysis: Teacher's lesson plans were another instrument to collect the data. The main goal of this instrument was to cross check the actual classroom practices. Two lesson plans would be used. The researcher used only two lesson plans because, all most all teachers lesson plan was the same.

\section{METHOD OF DATA ANALYSIS}

For the realization and successful accomplishment of the study, the collected data were recorded, edited, organized, discussed, analyzed, presented and interpreted in relation to research questions. These have been done both quantitatively and qualitatively by using descriptive statistical tools such as tables, percentages, mean, and Pearson correlation and for data collected through questionnaires and class room observation whereas words were used for data collected through interview and open-ended questions. In addition, the qualitative data was analyzed by transcribing respondent 's idea and views through narrations, descriptions, and discussions of different aspects of the study that could not be done through the quantitative method.

\section{RESULTS AND DISCUSSION}

\subsection{DESIGN AND IMPLEMENTATION OF LESSONS}

The mean score of using First Principle of Instruction Model across twelve questions with 40 secondary school teachers. The total mean is 2.80. Beginning the chapter by asking questions, designing lesson based on different problems, selecting appropriate instructional media, giving several opportunities to apply the newly acquired knowledge in the existing or actual problems and discussing in small groups with peers mean result is below the average mean, Teacher encouraged students to recall, to relate, to describe and to apply knowledge. Teachers demonstrated to students through examples. Teaches coached students' activities while they are working in small groups provided adequate feedback for students when they asked questions and encouraged students to explain in detail on their answers mean score is above the average mean.

Teachers asked questions to help students to make meaningful connection between the newly present information to their prior knowledge and teachers gave adequate opportunities for students to reflect and discuss on solution to specific questions mean result is nearly equal to the average mean. Most of the First Instruction Principles were practiced and used as tools for designing lessons. Therefor secondary school teachers design their lessons by using First Principle of Instruction Model and they practiced it effectively. However, data from open ended questions revealed that almost all of the respondents stated that most of them design their lesson plan based on the format which was prepared and given from the Amhara national regional state education bureau. Each and every teacher was used this format. The lesson plan format includes some principle from the First Principle of Instructional Model. The interview data replies that few teachers try to design and implement their lesson plan effectively but many of the teachers prepare lesson plan but not implement in their classroom. However, majority of the respondents or all most 8-10 participant states that teachers were prepare lesson plan based on the format, but they were not practiced in actual classroom effectively.

The alignment of First principle Instruction Model with Teachers Instructional Practices

\subsection{DATA FROM CLASSROOM OBSERVATIONS}

\section{Classrooms Observations}

\begin{tabular}{|c|c|c|c|c|c|c|c|c|c|}
\hline \multirow[t]{2}{*}{ No } & \multirow[t]{2}{*}{ Instructional principle } & \multicolumn{2}{|c|}{ Teacher A } & \multicolumn{2}{|c|}{ Teacher B } & \multirow{2}{*}{$\begin{array}{c}\text { Teacher } \\
\text { C } \\
\text { Yes }\end{array}$} & \multirow[b]{2}{*}{ No } & \multicolumn{2}{|c|}{$\begin{array}{l}\text { Teacher } \\
\text { D }\end{array}$} \\
\hline & & yes & No & yes & No & & & yes & No \\
\hline \multirow[t]{2}{*}{1} & Problems task centeredness & \multirow[t]{2}{*}{$\mathrm{x}$} & & & & & & & \\
\hline & $\begin{array}{l}\text { The teachers present information in the } \\
\text { context of real world. }\end{array}$ & & & $x$ & & $X$ & & $\mathrm{X}$ & \\
\hline
\end{tabular}


Bizu Kinfe Zekiros

\begin{tabular}{|c|c|c|c|c|c|c|c|c|}
\hline & $\begin{array}{l}\text { The teachers identify the learner task that } \\
\text { they will able to do or solve as a result of } \\
\text { completing the course }\end{array}$ & $\mathrm{x}$ & & $x$ & $x$ & & & $\mathrm{x}$ \\
\hline & $\begin{array}{l}\text { Learners engage in the problems or task not } \\
\text { just the action level }\end{array}$ & $\mathrm{x}$ & $\mathrm{X}$ & $x$ & $x$ & & $x$ & \\
\hline & $\begin{array}{l}\text { The teachers involved on the progression of } \\
\text { problems rather than a single problem }\end{array}$ & $\mathrm{x}$ & & $\mathrm{x}$ & $\mathrm{x}$ & & $X$ & \\
\hline \multirow[t]{5}{*}{2} & Activation principle & \multirow{2}{*}{$\mathrm{X}$} & \multirow[t]{2}{*}{$\mathrm{X}$} & \multirow[b]{2}{*}{$\mathrm{x}$} & \multirow[b]{2}{*}{$\mathrm{x}$} & & & \multirow[t]{2}{*}{$\mathrm{x}$} \\
\hline & $\begin{array}{l}\text { The teachers attempt to activated student's } \\
\text { relevant prior knowledge and experience by } \\
\text { asking different questions }\end{array}$ & & & & & & & \\
\hline & $\begin{array}{l}\text { The teacher's direct learners to recall, relate, } \\
\text { describe and apply knowledge from relevant } \\
\text { post experience }\end{array}$ & $\begin{array}{l}\mathrm{x} \\
\mathrm{x}\end{array}$ & & $x$ & $x$ & & $x$ & \\
\hline & $\begin{array}{l}\text { The teacher provides relevant experience } \\
\text { that can be used as foundation for new } \\
\text { knowledge }\end{array}$ & & & & & & & \\
\hline & $\begin{array}{l}\text { The teachers help leaner to recall or form } \\
\text { appropriate structure for organization the } \\
\text { new knowledge by asking questions }\end{array}$ & $\mathrm{x}$ & & $x$ & $x$ & & $x$ & \\
\hline \multirow[t]{6}{*}{3} & Demonstration principle & & & & & & & \\
\hline & & \multirow{2}{*}{$\mathrm{x}$} & & \multirow[b]{2}{*}{$\mathrm{x}$} & \multirow[b]{2}{*}{$\mathrm{x}$} & & & \multirow[t]{2}{*}{$\mathrm{x}$} \\
\hline & $\begin{array}{l}\text { The teachers demonstrate (show) learner } \\
\text { what is to be learned thought different } \\
\text { example and models }\end{array}$ & & & & & & & \\
\hline & $\begin{array}{l}\text { The teacher demonstrates examples that are } \\
\text { consistent with content to be taught }\end{array}$ & $\mathrm{x}$ & & $x$ & $x$ & & $\mathrm{x}$ & \\
\hline & $\begin{array}{l}\text { The teachers use leaners guiding technique } \\
\text { to follow up }\end{array}$ & $\mathrm{x}$ & $\mathrm{X}$ & $\mathrm{x}$ & $\mathrm{x}$ & & $\mathrm{x}$ & \\
\hline & $\begin{array}{l}\text { The teachers provide appropriate } \\
\text { instructional media to the content and } \\
\text { objective used to enhance leaning }\end{array}$ & $\begin{array}{l}\mathrm{x} \\
\mathrm{x}\end{array}$ & & $x$ & & $\mathrm{x}$ & $x$ & \\
\hline \multirow[t]{5}{*}{4} & Application principle & $\mathrm{x}$ & & \multirow[b]{2}{*}{$\mathrm{x}$} & \multirow[b]{2}{*}{$\mathrm{x}$} & & \multirow[b]{2}{*}{$\mathrm{x}$} & \\
\hline & $\begin{array}{l}\text { Learner have an opportunity to practice and } \\
\text { apply their newly acquired knowledge and } \\
\text { skill. }\end{array}$ & $\mathrm{x}$ & & & & & & \\
\hline & $\begin{array}{l}\text { Learners' practice is consistent with the } \\
\text { stated objectives }\end{array}$ & $\mathrm{x}$ & $\mathrm{X}$ & $x$ & $x$ & & $\mathrm{x}$ & \\
\hline & $\begin{array}{l}\text { The teacher provides leaner to use new } \\
\text { knowledge or skill to solve various problems } \\
\text { by relating problem with their real life }\end{array}$ & $\begin{array}{l}\mathrm{x} \\
\mathrm{x}\end{array}$ & & $\mathrm{x}$ & $\mathrm{x}$ & & & $\mathrm{x}$ \\
\hline & $\begin{array}{l}\text { Learners receive corrective feedbacks and } \\
\text { proper coaching }\end{array}$ & $\begin{array}{l}\mathrm{x} \\
\mathrm{x}\end{array}$ & & $x$ & $\mathrm{X}$ & & $x$ & \\
\hline
\end{tabular}


The Instructional Practices of Secondary School Teachers in Ethiopia: Hulet Eju Enesie Woreda

\begin{tabular}{|c|c|c|c|c|c|c|c|}
\hline 5 & Integration principle & \multirow[t]{2}{*}{$\mathrm{x}$} & \multirow[t]{2}{*}{$\mathrm{X}$} & \multirow[b]{2}{*}{$x$} & \multirow[t]{2}{*}{$\mathrm{x}$} & \multirow[b]{2}{*}{$\mathrm{x}$} & \\
\hline & $\begin{array}{l}\text { The teachers provide technique that } \\
\text { encourage learners to integrate the new } \\
\text { knowledge into their everyday life by giving } \\
\text { some examples }\end{array}$ & & & & & & \\
\hline & $\begin{array}{l}\text { The teacher provides an opportunity for } \\
\text { learners to publically demonstrate their new } \\
\text { skill or knowledge by asking their opinion } \\
\text { believes and skill they have }\end{array}$ & $\mathrm{x}$ & & $\mathrm{x}$ & $x$ & $\mathrm{x}$ & \\
\hline & $\begin{array}{l}\text { The teachers provide an opportunity for } \\
\text { leaner to reflect, discuss and defend their } \\
\text { new knowledge and skill. }\end{array}$ & $\mathrm{x}$ & & $\mathrm{x}$ & $x$ & $X$ & \\
\hline & $\begin{array}{l}\text { The teachers provide an opportunity for } \\
\text { leaner to create, invent and explore new skill } \\
\text { and knowledge }\end{array}$ & $\mathrm{x}$ & $\mathrm{X}$ & $\mathrm{x}$ & $x$ & & $x$ \\
\hline
\end{tabular}

The above Table, the showed the observation checklist which consists five major principles. Each of them has four sub principles. The checklist was prepared based on Merrill's First Principles of Instruction Model. Four different biology teachers were observed three times based on this principle. The principles are:

1) Problems/task centeredness. The mean score result indicated that teachers did not present information of content in real world, teachers did not identify learner's ability to solve problem after taking the lesson, learners did not take action at the level, and teachers didn't involve on the progression of the problems. Since the mean result of these principle is below average mean task centeredness principle was not practiced by secondary school teachers.

2) In the activation principle the mean result showed that this principle is practiced. That is teachers encouraged students to relate prior experience by asking questions. Teachers directed learners to recall, to describe and to apply knowledge from past experience. Teachers provided relevant experience that could be used as foundation base for new knowledge, and teachers helped learners to form appropriate structure for organizing the new knowledge by asking questions. The mean score of this principle was above average mean.

3) The third principle was demonstration. Teacher demonstrated leaner's what was to be learned through different examples. Teacher showed examples which were consisted with content to be learned. Teachers used learner's guiding technique to follow up. Teachers provided appropriate instructional media to the content and objective used to enhance learning. The mean of this principle is still above the average mean.

4) Application principle. The mean score of this principle is approximately equal to the average mean. The observation result showed that learners had the opportunity to practice and apply the newly acquired knowledge and skill. Leaners sometimes practiced with the stated objective. The teacher provided learners to use new knowledge and skill to solve various problems related to their real life. Learner received corrective feedback and proper coaching. Since the result was equal to the average, this principle practiced sometimes.

5) The last principle was integration. The observation result indicated that teachers did not provide techniques that encourage learners to integrate the newly knowledge and skill into their everyday life. The teacher didn't provide an opportunity to learners to publically demonstrate their new knowledge and skill. Teachers did not provide an opportunity to learners to discuss and defended their new knowledge and skill. The teachers did not provide an opportunity for learners to create, invent and explore new knowledge and skill. The mean score of these principles showed that teachers didn't practice. Since the means score was below the average.

The observation checklist result indicated that from the Five First Principle of Instruction Model, activation, demonstration and application principles, most of them were practiced by the teachers. The remaining two principles: problem centeredness and integration principles were not practiced. Even from the Five First Principle 


\section{Bizu Kinfe Zekiros}

of Instruction only three of them were practiced, the average mean showed that First Principles of Instruction Model align with teachers' instructional practices.

Besides these, at the time of observation teacher's ' $\mathrm{C}$ ' who earn his degree in Bachelor of education and teacher ' $B$ ' who is Bachelor of science with PGDT practiced First Principles of instruction Model better than teacher ' $A$ ' and 'D' who are Bachelor of science without PGDT. Regarding teaching experience, teacher ' $\mathrm{B}$ ' is less experienced than teacher ' $C$ '. It was observed that teacher ' $C$ ' was a better practioner of the model.

Generally, the observation result revealed that teachers' years of experience and using first principle of instructional model are directly proportional. When teachers' experience increases, first principles of instructional model also increase. In the words when the year of experience decreases, using first principles of instructional model also decreases.

It was observed that teachers who are graduated at regular program frequently used first principle of instructional model when they taught. Summer graduated teachers also used first principle of instructional model. But they used it less frequently than the regular graduated teachers. The observation result showed that distance graduated teachers practiced first principle of instructional model. However, they practiced it below the regular and summer graduated teachers.

\subsection{CHALLENGES IN IMPLEMENTING THE FIRST PRINCIPLES OF INSTRUCTION MODEL}

In addition to questionnaires and classroom observations, interview was conducted with school directors' supervisors and department heads to know the major challenges of teachers in implementing the First Principles of Instruction. Data from interview revealed that, several problems were identified: The majors' problems were grouped under three themes: These were teacher related, student related and resource related.

\section{Teachers Related Problems}

The interview results also showed that most PGDT teachers are not interested in their profession and they entered to this profession because of lack of money for surviving their life. These teachers lack pedagogical training, have attitudinal problems (understand teaching as simple work), didn't design and implement their lessons effectively. Teachers lack of motivation, interest and commitment. They have low understanding about lesson plan. They feel lesson plan as no value. They lack of awareness about First Principle of Instructional Model. Therefore, these all problems have their own factors teachers' instructional practice.

Teachers were carless enough that they were not committed, not motivated and not interested to design and to implement their lessons effectively. Lack of Training: for both teachers and school administrative about how an instruction is design and implement systematically.

From the interview results to solve the above problems, the school support teachers to design and practice lesson plan by giving moral and emotional support, by giving strong, positive commitments and suggestion, tried to allocate budget for materials and resource, support service gained through long- and short-term training about how teachers design their lessons effectively.

However, the schools support PGDT teachers by providing good opportunities to share some experience from more experienced teachers. These experienced teachers support them by giving personal and professional knowledge and skill. But some data replied that most of the time teachers were coming in the school with above five years of experience so need of support to these teachers.

\section{Students Related Problems}

Students have different background: these mean that there are many students who have different educational background since they come from different places and environment. These students have their own perspective and experience. Therefor to accommodate this different background most teachers lack some kinds of skill and ability.

Some students disturb in the classroom others didnot participate; still others didnot work their tasks effectively. Even other students have a problem of drug addicted and smoking cigarette which may affect the teaching learning processes generally and teachers' instructional practices particularly.

Low motivation: most of the time students have low motivation to learn because of many reasons. Like teachers lack of knowledge and skill, students studying habit, teaching methodology, feeling of pessimistic and so on. this all may affect the instructional practices of teachers. 
High numbers of students in the class: the number of the student and the class room size are also another factor of which affects the design and implementation of instruction. Classroom students should be manageable unless the instruction is not delivered effectively.

Language Barriers: this mean there is medium of instruction that English language. Most of the students have a problem of understanding concepts and ides through this language. There for there is a problem of communication. How the instructional design will be employed. This is the main reason to fail teacher's instructional practices.

In addition, data from open ended question showed that, majority of the respondents stated the following problems which affect their design and practice of lesson plan using First Principle of Instruction Model.

\section{Lack of resource and materials}

To have effective instructional practice in one school in general and in the classroom in particular, there should be adequate materials, teaching aids, instructional technology and rich resource. School environment: classrooms were very old and not attractive; chairs and desks are limited in numbers. These problems affect teachers' instructional practices.

Absence of instructional media, teaching aids, chalks and interactive black board. Therefore, without adequate materials teacher's instructional practice is not effective

\section{Shortage of Time}

Most of teachers use their time to finish course and teachers spent their time by doing different activities. Like extra-curricular activities, CPD program, giving tutorial.

\section{The Curriculum Itself}

Text books are very large and wide and they are not comfortable and interesting to practice. Contents and topics are very wide; for example, tasks and activities are not matched with real world problems. Because of this reason teachers didnot practice their instruction effectively rather they want to finish the course.

\section{DISCUSSIONS}

The First Principle of Instruction Model has been partially practiced by graduated secondary school teachers. The result revealed that regulars graduated teachers frequently used these principles. In comparison with regulars graduated teacher, summer and distance graduated teachers also practiced the First Principle of Instruction Model. But it is not frequency used. However, summer graduated teachers used more frequently than distance grated teachers. Research studies indicated that learning face to face and taking more time for learning give the opportunities to learn and practice more.

Secondary school teachers in Ethiopia had traditionally trained at university in four-year degree program which combined educational coursework and practicum experience with academic course in various discipline. However, recently the selection criteria and training strategies of secondary school teachers are changed (Adugna, 2012). That is the training is changed from the integrated four year of educational bachelor of degree to three-year degree course in majority of felids plus additional year of professional teachers training to obtain post graduate diploma in teaching (PGDT). The one-year professional educational program consists of training in educational foundation and pedagogy. But most of secondary school teachers are not effective in their teaching especially in designing their lesson plan using First Principle of Instruction Model.

For teaching, teachers who are graduated in bachelors of Science and bachelors of education, there are a significant different in using First Principle of Instruction Model. Bachelor of education graduated teachers had used this model frequently as compared with Bachelor of Science graduates. Bachelor of Science graduates who took PGDT and who didn't take PGDT had different frequency in designing and practicing the First Principle of Instruction Model. As it is compared to teacher who took PGDT training and who didn't take training, PGDT holders were practicing the model more than that they didn't take the training. It is understood that PGDT is valuable to practice the instructional model. 


\subsection{FIRST PRINCIPLE OF INSTRUCTION MODEL AND THE ACTUAL PRACTICES}

The finding indicated that most of the First Principles of Instruction Model were practiced by secondary school teachers. It was observed that majority of the principles were practiced. Besides this, a minimum one of the five elements in the principle was practiced by the teachers. Beginning the chapter by asking questions, designing lesson based on different problems, selecting appropriate instructional media, giving several opportunities of apply the newly acquired knowledge in the actual problems and discussing in small groups with their peers' mean is below the average mean. It is clear that the problem centered principles have been practiced rarely as compared with other principles. However (Francom, 2014; Merrill, 2007) proposed that this task-based principle provide specific demonstration of particular task. Similar to that, the learner will be confronted in real life setting. Other principles such as, teachers asked questions to make students integrate in meaningful connection between the newly presented information to their background knowledge and teacher gave adequate to opportunity for students to reflect and disuses on solution to the specific questions mean is nearly equal to the average mean. From the finding it is explained that teachers encouraged student to recall, relate, describe, apply and explain the acquired knowledge, they demonstrated to students by using example, teacher coached students' activities while working in small groups and provided adequate feedbacks for students' questions mean score is above the average mean. It is understood that demonstration principles were widely practiced by secondary school teachers. Supporting this idea (Merrill, 2002) proposed that demonstration principle is the most important dimensions for successful learning.

\section{CONCLUSIONS}

Based on the findings, it is concluded that even though there are many different models of +designing instruction were existed, first principle of instruction model is the one which aligned with secondary school teachers' instructional practices. Secondary school teachers' lesson plan has some elements of First Principle of Instruction Model. However, some findings indicated that teachers didn't practice their instruction effectively (Simegn, 2012). The reason was because of many problems like teachers lack of commitment, motivation and interest, teacher low understanding about First Principle of Instruction Model, students' unnecessary behavior, Teachers lack short- and long-term training, shortage of time, resource material and the government did not avail conducive environment to support teachers to design effective environment. Similarly, another study also states that Ethiopian secondary school teachers have many problems during designing lesson plan which Lack of adequate support, lack of interest, commitment and motivation to their profession, attitudinal problems (Melesse, 2015).

\section{RECOMMENDATIONS}

Based on the findings of the study, the following recommendations have been forwarded. Wereda education office and general secondary school directors and supervisors should prepare or offer short- and long-term training, seminars and workshop for teachers to increase their effectives in their instructional practices. Wereda education office and general secondary school directors and supervisors should have considered offering adequate instructional media and materials resource for teachers so as to improve and increase their instructional practices effectively. Secondary school directors and supervisors should help teachers to have both personal and professional knowledge and skill. They should also support them by creating good educational environment. Secondary school directors, supervisors and department heads should facilitate supervision programs to check whether teachers design and implement their instruction effectively and to give constructive comments and suggestions on their weakness. Teachers and schools should be given the right to develop their own format to prepare their lesson with sufficient information. Wereda education bureau and supervisor should have a system to be designed in which teachers with neighboring schools have talks and discusses on such issues.

\section{SOURCES OF FUNDING}

This research received no specific grant from any funding agency in the public, commercial, or not-for-profit sectors. 
The Instructional Practices of Secondary School Teachers in Ethiopia: Hulet Eju Enesie Woreda

\section{CONFLICT OF INTEREST}

The author have declared that no competing interests exist.

\section{ACKNOWLEDGMENT}

None.

\section{REFERENCES}

[1] Creswell, J. W. (2012) Educational Research. Planning Conducting and Evaluating Research (4th) Boston Pearson education Inc.

[2] Daba, T.\& Anbesaw, M. (2016). Factor Affecting the Implementation of Practice activities in science Education in some selected secondary and preparatory school of Afar Region. International Journal of Environmental a d Science Education.11 (12).

[3] Daggett, W.R, (2011). The Daggett System for Instruction. International Center for Leader Ship in Education.

[4] Francom, G. \& Gardner, J. (2014) what is Task-Centered Learning. Tech Trends 58(5)

[5] Francom, G., Bybee, D., Woltersberger, M., Merrill, D. (2009) Biology 100: Task Centered, Peer Interactive Redesign. Tech Trends 53(3) 85-100

[6] Gardner, J. (2011) Teaching the Efficiency of Merrill's First Principle of Instruction in improving understandably in introductory undergraduate Biology course. Unpublished doctoral dissertations.

[7] Kali, Y., Levin-Peled, R., Dor, Y.J. (2009). The Role of Design Principle in Design Cause That Promote Collaborative Learning in Higher Education. International Journal of Computer in Human Behavior. Elsevier.

[8] Melesse, T. (2015). The Utilization of Instructional Process in Higher Education Institutions of the Amhara Region Ethiopia. Science Technology and Art Research journal 4(4), 182-193.

[9] Merrill,. M.D. (2009) Finding (effective, efficient and engaging) Instruction Educational Technology, 49(3) 1526Technology in Education 40(1) 5-22

[10] Merrill, M. D. (2007) A task centered instructional strategies. Journal of Research on Technology in Education 40(1) 5-22

[11] Merrill, M.D, (2002). First Principles of Instruction. Educational Technology Research \& Development 50(3).

[12] Merrill, M.D. (2006). First Principles of Instruction Analysis. Trends and issue in instructional design and technology 2nd prentice Hall. Inc

[13] Micheal, F. Salman, M. Ayinla, O. (2012) Effects of Teachers Instructional Strategies Pattern on Senior Secondary School students Performance Mathematics Word Problems. Journal of Education and Practice.

[14] Simegn, B. (2012) A study of secondary school EEL teachers pedagogical Beliefs and class Room Practice. Unpublished Doctoral Dissertation Addis Ababa University.

[15] Smith, p. L \& Ragan. T.J (2005) Instructional Design (3rd) Hoboken, N J: Wiley

[16] Tiruneh, D.T. Weldeslassie, A.G. Kassa, A. Tefera, Z. Decock, M. Elen J, (2015). Systematic Design of Learning Environment for Domain Specific \& Domain General Critical Thinking Skill. Educational Technology and Research Development. 